\title{
Analisis Pengungkapan Triple Bottom Linedan Faktor yang Mempengaruhi; Lintas Negara Indonesia dan Jepang
}

\author{
Sandra Aulia $\mathrm{Z}^{1 *} \& \mathrm{~Tb}$. Mh. Idris Kartawijaya ${ }^{2 *}$ \\ ${ }^{1}$ Program Studi Akuntansi Program Vokasi Universitas Indonesia \\ ${ }^{2}$ Fakultas Ekonomi Universitas Indonesia
}

\begin{abstract}
ABSTRAK. Kinerja perusahaan saat ini tidak hanya cukup diukur secara ekonomi (single bottom line) namun juga secara sosial dan lingkungan (triple bottom line). Penelitian ini bermaksud untuk menganalisis pengungkapan TBL dan faktor-faktor yang mempengaruhinya dengan sampel perusahaan-perusahaan di negara Indonesia dan Jepang.

Penelitian ini menggunakan data sekunder atas 50 perusahaan terbesar di masing-masing Negara Indonesia dan Jepang. 22 kriteria pengungkapan dikembangkan untuk setiap area pengungkapan yaitu ekonomi, sosial dan lingkungan. Informasi pengungkapan diuji dalam laporan tahunan, laporan terpisah lainnya dan website perusahaan.

Hasil penelitian menemukan bahwa pengungkapan TBL pada perusahaan Jepang lebih luas dibandingkan dengan di Indonesia, terutama pada pengungkapan lingkungan. Pengungkapan TBL lebih luas terjadi pada perusahaan yang memiliki ukuran perusahaan yang lebih besar dan likuiditas yang lebih tinggi. Faktor industri manufaktur mempengaruhi pengungkapan mengenai lingkungan pada perusahaan di Indonesia. Pengungkapan total TBL lebih didominasi oleh pengungkapan non ekonomi.
\end{abstract}

Kata kunci: TBL, ekonomi, sosial, lingkungan, Indonesia, Jepang

ABSTRACT.Current firm performance is not only measured by economic term (single bottom line) but also by social and environmental (triple bottom line). Purposes of this research are analyzing of TBL disclosure and influences factors, by using sample of companies in Indonesia and Japan.

This paper investigates Triple Bottom Line (TBL) disclosure of 50 of the largest Indonesian and Japanese companies by using secondary data. Twenty two disclosure criteria were developed for each of the TBL disclosure areas: economic, social, and enviromental. Disclosure information was examined in annual reports, separate or stand-alone report and company's website. Regression analysis has been used to examine the determinants of TBL disclosure practice empirically.

Our result indicated that, for total of TBL disclosure (combining economic, social and environmental catagories), the extent of reporting is higher for firm with larger size and higher liquidity, and special for environmental disclosure for firm with membership in the manufacturing industry for Indonesian companies. Futher analysis indicated that the results of the total TBL disclosure are primarily driven by non-economic disclosures. We also found that the extent of overall TBL disclosure is higher for Japanese firms, with environmental disclosure being the main key. This result could be attributed to the different national cultures and to the regulation environment between Indonesian and Japan.

Keywords: TBL, economic, social, environment, Indonesia, Japan 


\section{PENDAHULUAN}

\section{Latar Belakang}

Sudah menjadi fakta banyaknya resistensi masyarakat sekitar di berbagai tempat dan waktu muncul ke permukaan terhadap perusahaan yang dianggap tidak memperhatikan aspek-aspek ekonomi, sosial dan lingkungan. Di dalam akuntansi konvensional, pusat perhatian perusahaan hanya terbatas kepada stockholders dan bondholders, yang memberikan kontribusi langsung terhadap perusahaan, sedangkan pihak lain sering terabaikan. Kemudian berbagai kritik muncul, akuntansi konvensional dianggap tidak dapat lagi mengakomodir kepentingan stakeholder. Sehingga muncullah konsep akuntansi yang baru, yang disebut sebagai Corporate Social Responsibility (CSR). Informasi yang diungkapkan tidak hanya informasi keuangan perusahaan, namun juga mengenai dampak (externalities) sosial dan lingkungan hidup yang diakibatkan aktivitas perusahaan. Sehingga perusahaan bukan lagi sebagai entitas yang hanya mementingkan tujuannya sendiri namun harus memperhatikan kepentingan lingkungan dan sosialnya.

Perubahan paradigma dari pertumbuhan ekonomi (economic growth) menjadi pembangunan yang berkelanjutan (sustainable development $)^{1}$, memerlukan dua pra kondisi yaitu social responsibility dan environment responsibility. Terpenuhinya tanggung jawab sosial dan lingkungan akan lebih memudahkan tercapainya pembangunan yang berkelanjutan. Sebab sumber-sumber produksi yang sangat penting bagi aktivitas perusahaan dapat lebih terjaga. Dengan konsep pembangunan yang berkelanjutan, perusahaan tidak lagi dihadapkan pada tanggung jawab yang berpijak pada single bottom line (SBL), yaitu nilai perusahaan (corporate value) yang direfleksikan dalam kondisi ekonomi (financial) saja. Tapi lebih berpijak pada triple bottom lines (TBL)yaitu ekonomi, sosial dan lingkungan. Karena kondisi keuangan saja tidak cukup menjamin nilai perusahaan tumbuh secara berkelanjutan (sustainable).

Penelitian ini bermaksud untuk menganalisis sejauh mana luaspengungkapan triple bottom lines di Indonesia dibandingkan dengan Jepang yang menurut Jennifer Ho dan Taylor (2007)pengungkapan sosial dan lingkungan di Jepang sangat rinci dan mendalam, terutama pengungkapan mengenai lingkungan. Hal ini tidak terlepas dari peran pemerintah selaku

1hasil Konferensi Tingkat Tinggi Bumi (Earth Summit) di Rio de Janeiro Brazilia 1992 
regulator, pemerintah di Jepang memberikan pedoman khusus untuk pengungkapan informasi kepada publik. Lain halnya dengan Indonesia, hasil penelitian Nurhayati, Brown dan Tower (2006) menunjukan bahwa pengungkapan lingkungan pada perusahaan di Indonesia masih sangat rendah. Penelitian ini akan menguji faktor-faktor apa saja yang mempengaruhi perusahaan mengungkapkan informasi mengenai TBL. Penelitian ini penting untuk dilakukan karena penelitian TBL belum menjadi topik yang diteliti secara mendalam di Indonesia terutama bila dibandingkan dengan negara lain, Jepang khususnya. Pengungkapan Pengungkapan dilakukan melalui laporan tahunan, laporan sustainanble yang terpisah dan website perusahaan. Analisis regresi digunakan untuk melakukan pengujian hipotesis.

Penelitian ini menemukan bahwa luasnya pengungkapan TBL (kombinasi ekonomi, sosial dan lingkungan) lebih besar untuk perusahaan dengan ukuran yang lebih besar, dan likuiditas yang lebih tinggi. Analisa lebih jauh mengenai pengungkapan lingkungan yaitu luas pengungkapan pada perusahaan Jepang dan Indonesia lebih didominasi oleh industri manufaktur. Pengungkapan ekonomi, sosial dan lingkungan lebih luas untuk perusahan di Jepang.
Penelitian ini diharapkan dapat memberikan bukti empiris mengenai pentingnya pengungkapan TBL di Indonesia, dan diharapkan penelitian ini dapat memberikan masukan kepada pemerintah agar dapat memberikan pedoman khusus untuk pengungkapan kegiatan TBL yang dilakukan perusahaan baik dalam laporan keuangan, website ataupun laporan terpisah lainnya guna memberikan informasi yang komprehensif kepada stakeholders.

\section{Studi Literatur}

Dalam beberapa dekade terakhir perusahaan telah mengakui bahwa keuntungan perusahaan yang berkelanjutan bukan hanya mengejar keuntungan finansial, bukan hanya peningkatan nilai pemegang saham, namun yang paling baik adalah dicapai melalui kerangka kerja yang luas di bidang ekonomi, sosial, lingkungan dan nilai-nilai etika serta tujuan bersama yang melibatkan interaksi antara perusahaan dan berbagai pemangku kepentingan. Perubahan paradigma ini, mencakup keuangan, sosial, dan lingkungan ke dalam komitmen perusahaan untuk pertumbuhan dan keuntungan berkelanjutan, sering disebut sebagai "triple bottom line." ( $\mathrm{Zu}$, 2009). Gagasan "Triple Bottom Line" (TBL) semakin mendapat tempat di manajemen 
konsultasi, investasi dan LSM selama beberapa tahun terakhir. Konsep ini diciptakan oleh John Elkington pada pertengahan tahun 1999an dalam bukunya "Cannibals with Forks: the Triple Bottom Line of 21 st Century Business". Akhir tahun 1990an istilah "triple bottom line" telah menyebar dan diakui oleh dunia. Ide paradigm TBL melihat sebuah keberhasilan perusahaan harus diukur tidak hanya dengan pendekatan keuangan tradisional, tetapi juga oleh sosial dan lingkungan. TBL menangkap spektrum yang lebih luas dari nilai-nilai dan kriteria untuk mengukur kesuksesan organisasi (dan masyarakat): ekonomi, lingkungan dan sosial, hal ini berarti memperluas kerangka kerja pelaporan tradisional

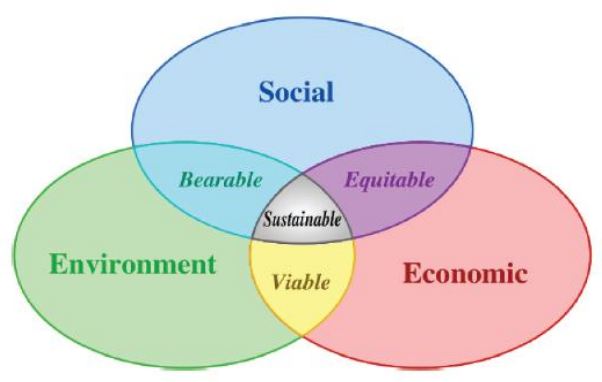

Teori yang digunakan dalam penelitian ini adalah teori terkait dengan pengungkapan yaitu teori agency, signalling, dan litigation (Gray et al., 1995a, 1996; Guthrie dan Parker, 1990; Patten, 1992; Roberts, 1992). Pertama, teori agensi, yang mengatakan bahwa shareholders akan melakukan price-protect untuk menghindari kecurangan yang untuk memperhitungkan kinerja sosial dan lingkungan di samping kinerja keuangan. Ini juga menangkap esensi pembangunan berkelanjutan dengan mengukur dampak dari kegiatan organisasi di dunia (Zu, 2009, p. 29).

Sisi Positif TBL mencerminkan peningkatan nilai perusahaan, termasuk profitabilitas dan nilai pemegang saham, sosial, manusia, dan lingkungan. Gambar 2.1 menjabarkan keterkaitan antara dimensi ekonomi, sosial dan lingkungan. TBL adalah cara yang inovatif bagi para eksekutif dan perusahaan untuk menemukan jalan menuju konsep berkelanjutan yang menguntungkan masa depan di era akuntabilitas lingkungan dan sosial. (Zu, 2009)

\section{Gambar 2.1 Triple Bottom Line dan} sustainable development (Sumber: $\mathrm{Zu}, 2009$ )

dilakukan oleh managemen. Sehingga untuk menghindari hal tersebut, secara sukarela managemen perusahaan mengambil beberapa tindakan, termasuk melakukan pengungkapan. Kedua, teori signaling, mengatakan bahwa pengungkapan sukarela adalah satu maksud bagi perusahaan atau manager untuk membedakan diri mereka dari yang 
lainnnya, seperti kualitas dan kinerja perusahaan. Ketiga, teori legitimasi (Dowling \& Pfeffer, 1975), pengungkapan sosial berarti "deal" terhadap tekanan politik dan sosial (M. Freedman, B. Jaggi, 2005). Perusahaan adalah bagian dari tujuan sosial. Dengan mengungkapkan informasi sosial dan lingkungan, perusahaan berusaha menyampaikan kepada stakeholder bahwa mereka telah memenuhi tujuan sosial dan lingkungan yang dapat mengurangi tekanan publik. Sehingga perusahaan akan melegitimasi kinerja mereka dengan melakukan pengungkapan sosial dan lingkungan (M. Freedman, B. Jaggi, 2005). Legitimasi teori banyak diuji dibeberapa studi empirik dan hasilnya konsisten dengan teori.

Beberapa penelitian memberikan bukti empirik terkait dengan pengungkapan ekonomi, sosial dan lingkungan seperti Hackston dan Milne (1996) menginvestigasi pengungkapan sosial dan lingkungan untuk perusahaan di New Zealand, dan temuannya mengindikasikan isu sosial dan lingkungan menjadi perhatian yang signifikan. Guthrie dan Parker (1990) menemukan bahwa pengungkapan sosial lebih tinggi untuk perusahaan Amerika dan Inggris dibandingkan perusahaan di Australia. Gamble et al. (1996) menguji laporan tahunan mengenai pengungkapan lingkungan untuk sampel perusahaan dengan 9 industri dan 27 negara dari tahun 1989 sampai 1991, hasilnya menunjukkan perusahaan yang beroperasi dalam negara dengan tingkat tekanan sosial yang tinggi dan berada dalam pasar modal yang berkembang mengungkapkan lebih banyak mengungkapkan informasi mengenai lingkungan. Craig dan Diga

$$
\text { menganalisa }
$$

praktik pengungkapan dari laporan tahunan atas 5 negara ASEAN yaitu Singapura, Malaysia, Filipina, Indonesia dan Thailand, hasilnya menunjukan bahwa secara keseluruhan perusahaan ASEAN terlihat enggan mengungkapkan informasi yang sensitif terkait dengan politik dan sosial seperti informasi aktivitas tenaga kerja sosial dan program lingkungan, penelitian tersebut menyimpulkan bahwa pelaporan perusahaan ASEAN lebih cenderung terorientasi terhadap penyedia modal daripada stakeholder secara keseluruhan seperti pegawai, pemerintah dan komunitas lainnya. Jennifer Ho dan Taylor (2007) melakukan pengujian atas pengungkapan TBL di 50 perusahaan AS dan Jepang, hasil penelitian menunjukkan bahwa luas pengungkapan TBL didominasi oleh pengungkapan nonekonomi dan luas pengungkapan TBL lebih tinggi pada perusahaan Jepang disbanding Amerika, terutama dari 
pengungkapan lingkungan. Hal ini terkait dengan perbedaan dalam budaya nasional, peraturan lingkungan, dan faktor-faktor institusional lainnya.

Dapat dikatakan bahwa banyak penelitian mengenai pengungkapan sosial dan lingkungan yang fokus di negara Eropa dan sedikit sekali penelitian yang mengambil sampel negara Asia terutama Indonesia. Maka dalam penelitian ini kami menguji penelitian terdahulu dengan mengambil sampel negara Jepang sebagai salah satu negara dengan wilayah yang terbatas namun mampu mengoptimalkan sumber daya yang ada dan memiliki tingkat pertumbuhan ekonomi yang tinggi (sebelum terjadinya krisis karena gempa tahun 2011) dan dibandingkan dengan perusahaan di Indonesia, yang jarang menjadi objek penelitian mengenai sosial dan lingkungan

\section{TINJAUAN KEPUSTAKAAN DAN PERUMUSAN HIPOTESIS}

\subsection{Pengembangan Hipotesis}

\section{a. Ukuran perusahaan}

Jensen dan Meckling

mengatakan perusahaan besar biasanya memiliki agency costs yang lebih besar karena informasi asimetri yang lebih besar antara manager dan shareholders. Agency costs meningkat dengan adanya modal dari luar (outside capital) dan perusahaan besar biasanya memiliki proporsi modal luar yang lebih besar. Sehingga untuk mengurangi agency costs, perusahaan besar akan lebih mengungkapkan informasi. Guthrie dan Parker (1990) mengatakan baik dari agency theory dan legitimacy theory berisi argumen mengenai hubungan antara ukuran dan pengungkapan perusahaan. Skinner (1994) mengatakan bahwa perusahaan besar memiliki insentif yang lebih besar untuk mengungkapkan semuanya untuk meminimalisir kemungkinan adanya biaya litigasi. Perusahaan besar adalah subjek peraturan pengawasan (Watts dan Zimmerman 1986) sehingga biasanya secara sukarela pengungkapan informasi lebih kepada publik untuk mengurangi biaya politik dan meningkatkan modal (Chow dan Wong-Boren, 1987; Lang and Lundholm 1993). Biaya politik juga digunakan untuk menjelaskan hubungan yang positif antara ukuran perusahaan dan pengungkapan. Perusahaan yang lebih besar biasanya lebih mengungkapkan untuk menghindari serangan politik, permintaan untuk melakukan pertanggungjawaban sosial, peraturan yang lebih besar, ancaman nasionalisme atau pemisahan dari entitas atau industri (Jensen dan Meckling, 1976; Watts dan Zimmerman, 1978). Penelitian Singhvi dan Desai (1971) dan Wallace dan Naser (1995) mengatakan bahwa perusahaan yang lebih kecil merasa bahwa 
pengungkapan lebih akan merugikan posisi persaingan usaha dibanding perusahaan besar. Penelitian Cowen et al. (1987); Deegan dan Gordon (1998), Hackston dan Milne (1996) mengatakan bahwa ukuran perusahaan berhubungan dengan tekanan publik terhadap manajemen lingkungan yang dilakukan perusahaan. Dengan kata lain perusahaan besar biasanya akan mengungkapkan semua informasi perusahaan (Holland dan Boon Foo, 2003). Berdasarkan penelitian diatas maka hipotesa untuk menguji penelitian ini adalah :

$\mathbf{H}_{1}$ : Ukuran perusahaan berhubungan positif dengan luasnya pengungkapan TBL.

\section{b. Leverage}

Jensen dan Meckling (1976) mengatakan bahwa perusahaan dengan leverage yang lebih tinggi memiliki biaya monitoring yang tinggi. Sehingga manajemen akan secara komprehensif mengungkapkan untuk tujuan monitoring agar memastikan kepada debt holders kemampuan untuk membayar. Hal ini dilakukan untuk mengurangi agency costs. Sehingga di presiksi perusahaan yang memiliki leverage yang tinggi cenderung untuk meningkatkan pengungkapan TBL. Berdasarkan penelitian diatas maka hipotesa untuk menguji penelitian ini adalah :
$\mathbf{H}_{2}$ : Financial Leverage berhubungan dengan luasnya pengungkapan TBL.

\section{c. Profitabilitas}

Manager pada perusahaan yang profitable memiliki dorongan atau insentif yang lebih untuk mengungkapkan informasi untuk mendukung keberlanjutan posisi mereka dan juga kompensasi yang diperoleh (Wallace et al., 1994; Inchausti, 1997). Sebaliknya, entitas dengan kinerja ekonomi yang rendah cenderung tidak memiliki kemampuan finansial untuk mengungkapkan informasi lebih lanjut (Ullman, 1985; Meek, Roberts dan Gray, 1995). Pirchegger dan Wagenhofer (1999) dalam Xiao et al. (2004) menemukan bahwa ukuran perusahaan dan profitabilitas berhubungan dengan pengungkapan di internet oleh perusahaan-perusahaan Austria, namun tidak mempengaruhi pengungkapan di internet oleh perusahaan di Jerman. Beberapa penelitian mendukung adanya hubungan yang positif antara profitabilitas perusahaan dan tingkat pengungkapan (Singhvi dan Desai, 1971; Roberts, 1992) sementara yang lain tidak menemukan korelasi signifikan (Patten, 1991; Hackston dan Milne, 1996; Williams, 1999). Berdasarkan penelitian diatas maka hipotesa untuk menguji penelitian ini adalah: 
$\mathbf{H}_{\text {s: }}$ Profitabilitas perusahaan berhubungan dengan luasnya pengungkapan TBL.

\section{d. Liquiditas}

$$
\text { Oyelere et al. (2003) dalam }
$$

Jennifer Ho dan Taylor (2007) mengatakan bahwa likuiditas perusahaan adalah faktor penentu yang penting bagi pengungkapan yang dilakukan perusahaan, karena Investor, kreditor, regulator dan pengguna lainnya sangat memperhatikan status going concern perusahaan. Jennifer Ho dan Taylor menemukan bahwa perusahaan yang memiliki likuiditas yang rendah memiliki luas pengungkapan yang lebih tinggi. Berdasarkan penelitian diatas maka hipotesa untuk menguji penelitian ini adalah:

$\mathbf{H}_{4}$ : Likuiditas perusahaan berhubungan positif dengan luasnya pengungkapan TBL.

\section{e. Kepemilikan Asing}

Investor asing memiliki kecenderungan mempersoalkan masalah pengadaan bahan baku dan proses produksi yang terhindar dari munculnya permasalahan lingkungan, dan investor mulai mempertimbangkan keperdulian perusahaan terhadap lingkungan dalam bentuk keputusan investasinya (Satyo, 2005). Pemegang saham asing dihadapkan pada besarnya tingkat informasi asimentri, sehingga untuk menghindari potensi kerugian yang ditimbulkan dengan adanya asimetri informasi, berlandaskan teori agensi maka perusahaan dengan kepemilikan asing akan memberikan tambahan informasi dengan melakukan pengungkapan sukarela yang dapat memberikan kesan bahwa perusahaan lebih transparan (Xiao et al, 2004). Berdasarkan penelitian diatas maka hipotesa untuk menguji penelitian ini adalah:

$\mathbf{H}_{5}$ : Kepemilikan asing berhubungan dengan luasnya pengungkapan TBL.

\section{f. Corporate governance}

Corporate governance yang digunakan dalam penelitian Halme dan Huse (1997) yaitu boards of directors. Cahill dan Engelman (1993), Greeno (1993) dalam Halme dan Huse (1997) mengatakan bahwa manajemen di dukung oleh board, board adalah yang mendorong segala progres lingkungan. Sehingga baik board dan eksekutif memiliki pengaruh yang besar terhadap kinerja lingkungan perusahaan (Cahill dan Engelman (1993) dalam Minna dan Morten (1996). Dari sudut pandang teori legitimasi, kehadiran direktur independen dalam komposisi dewan perusahaan dapat memperkuat persepsi publik terhadap legitimasi perusahaan. Masyarakat akan menilai lebih tinggi suatu perusahaan jika 
memiliki independen direktur yang seimbang atau banyak dalam dewan perusahaan, karena kondisi seperti ini menandakan lebih efektifnya pengawasan dalam aktivitas managemen perusahaan.

Direksi dianggap sebagai komponen penting dalam corporate governance yang baik (Mallin, 2004 dalam Nurhayati, Brown dan Tower 2006). Direktur non-eksekutif yang pada umumnya lebih independen terhadap manajemen mungkin memiliki lebih banyak kekuatan untuk mendorong manajemen mengungkapkan informasi secara sukarela seperti informasi lingkungan kepada stakeholders. Sehingga, jumlah direktur independen yang dominan dalam dewan akan menghasilkan pengungkapan sukarela yang lebih besar (Haniffa dan Cooke, 2002; Eng dan Mak, 2003 dalam Nurhayati, Brown dan Tower, 2006). Beberapa penelitian sebelumnya menemukan bukti yang tidak konsisten antara hubungan antara komposisi dewan dan sejauh mana pengungkapan. Haniffa dan Cooke (2002) dan Eng dan Mak (2003) menemukan hubungan negatif, Chen dan Jaggi (2000) menemukan hubungan yang positif. Independen director dalam dewan direksi memiliki pengaruh besar terhadap kinerja lingkungan (Cahill dan Engelman (1993) dalam Halme dan Huse (1997) dan jumlah direktur independen yang dominan dalam dewan akan menghasilkan pengungkapan sukarela yang lebih besar (Haniffa dan Cooke, 2002; Eng dan Mak, 2003 dalam Nurhayati, Brown dan Tower, 2006). Berdasarkan penelitian diatas maka hipotesa untuk menguji penelitian ini adalah:

$\mathbf{H}_{6}$ : Corporate governance berhubungan dengan luasnya pengungkapan TBL

\section{g. Industri}

Perusahaan dalam industri yang sama cenderung memenuhi kebijakan pengungkapan informasi yang sama. Argumen adverse selection mengatakan bahwa perusahaan yang tidak mengikuti kebijakan pengungkapan yang ada dalam industri tersebut diinterpretasikan oleh pasar bahwa perusahaan tersebut menyembunyikan berita buruk (Oyelere et al., 2003 dalam Jennifer Ho dan Taylor, 2007). Jennifer Ho dan Taylor (2007) menemukan bahwa industri manufaktur memiliki tingkat pengungkapan yang lebih tinggi dibandingkan dengan industri lainnya. Berdasarkan penelitian diatas maka hipotesa untuk menguji penelitian ini adalah:

$\mathbf{H}_{7}$ : Keanggotaan industri berhubungan dengan luasnya pengungkapan TBL.

\section{h. Negara}

Budaya suatu negara dianggap mempengaruhi jenis tekanan lingkungan 
dan pelaporan mengenai lingkungan (Gallhofer et al. 2000). Williams (1999) menemukan bahwa budaya berhubungan signifikan menentukan kualitas informasi pengungkapan sukarela akuntansi lingkungan dan sosial akuntansi dengan menggunakan region Asia-pasifik. Ball (1995) dan Nobes (1998) menyatakan bahwa tingkat pengungkapan perusahaan lebih tinggi pada suatu Negara yang memiliki equity financing daripada Negara yang lebih pada debt financing. Menurut Debreceny et al. (2002) karena equity holders menjadi residual owners yang akan menangung resiko lebih besar daripada debtholders. Aerts et al. (2006), tindakan dan keputusan manajer perusahaan tergantung pada lingkungan hukum yang ada dimasing-masing negara seperti hukum yang relevan, regulasi dan rekomendasi profesional. Berdasarkan penelitian diatas maka hipotesa untuk menguji penelitian ini adalah :

$\mathbf{H}_{\mathbf{s}}$ : Terdapat perbedaan signifikan antara luas pengungkapan di Indonesia dan di Jepang

\section{METODOLOGI PENELITIAN}

Indeks TBL terdiri dari 22 item untuk masing-masing luas pengungkapan ekonomi, sosial dan lingkungan pada perusahaan di Indonesia dan Jepang. Pemilihan 66 item tersebut menggabungkan penelitian Jennifer Ho dan Taylor (2007), GRI (the Global Reporting Initiative) 2007, dan beberapa penelitian lainnya. GRI diperbaharui setiap 2 tahun sehingga penelitian ini menggunakan GRI tahun 2007 karena perusahaan yang dijadikan sampel adalah perusahaan tahun 2009. Indeks diperoleh dari analisa pengungkapan pada laporan tahunan, website perusahaan dan laporan terpisah lainnya ${ }^{2}$ seperti environmental report,

\footnotetext{
${ }^{2}$ Penelitian Roberts (1991) dan Unerman (2000) mengatakan bahwa fokus terhadap laporan tahunan akan menghasilkan gambaran yang kurang lengkap dengan banyaknya laporan yang berkembang. Laporan terpisah dapat memberikan signal (possibly believe) bahwa perusahaan memperhatikan masalah CSR yang sama pentingnya dengan laporan keuangan (Holland, 1993).
} 
sustainability report, dan CSR report dengan menggunakan metode content analysis yaitu menganalisis pengungkapan perusahaan dalam semua laporan yang menyediakan informasi TBL. Penilaian dalam melakukan content analysis terdiri dari pemberian skor dari o hingga $3^{3}$.

Untuk menjawab pertanyaan penelitian terkait dengan faktor-faktor yang menentukan pengungkapan TBL diestimasi melalui multiple regresion model sebagai berikut:

\section{Model Penelitian}

$\operatorname{INDEX}_{i n}=\alpha_{0}+\alpha_{1} \mathrm{SIZE}_{i n}+$ $\alpha_{2}$ PROFIT $_{i n}+\alpha_{3}$ LIQUID $_{i n}+\alpha_{4}$ LEV $_{i n}+$ $\alpha_{5}$ FOREIGN $_{i n}+\alpha_{6}$ BOD_C $_{i n}+\alpha_{7}$ IND $_{i n}+$ $\alpha_{8} \mathrm{CTRY}_{i n}+\mathrm{e}_{i n}$

-Definisi variabel dalam model disajikan dalam Lampiran I-

\section{Jumlah Sample, Teknik dan Sumber}

Pengumpulan Data

\footnotetext{
${ }^{3}$ Nilai ojika item tidak diungkapkan/informasi tidak tersedia, 1 jika informasi diungkapkan hanya secara umum, 2jika informasi diungkapkan secara spesifik dan non-kuantitatif, 3jika informasi diungkapkan secara spesifik baik dalam ukuran monetary / kuantitatif
}

Jumlah sampel adalah 100 perusahaan yaitu 50 perusahaan untuk masing-masing negara pada industri non keuangan tahun 2009 yang diurut berdasarkan ukuran perusahaan tertinggi dengan menggunakan market capitalization (Jennifer Ho dan Taylor, 2007 dan Holland dan Boon Foo, 2003). Perusahaan yang diteliti adalah perusahaan yang go public dan telah diaudit. Pengumpulan data diperoleh dari data sekunder. Data keuangan diperoleh dari data Osiris yang telah diperiksa kebenarannya dengan laporan tahunan yang dikeluarkan perusahaan. Prosedur yang digunakan dalam menguji hipotesis adalah Ordinary Least Square (OLS) regression karena OLS dapat memberikan penduga koefisien regresi yang baik atau bersifat BLUE (Best Linear Unbiased Estimator). 
Tabel 1.

Klasifikasi Industri dalam perusahaan Sampel

\begin{tabular}{|l|l|l|l|l|}
\hline \multirow{2}{*}{ Industri } & \multicolumn{2}{|c|}{ Indonesia } & \multicolumn{2}{c|}{ Jepang } \\
\cline { 2 - 5 } & Jumlah & $\%$ & Jumlah & \multicolumn{2}{c|}{$\%$} \\
\hline Manufacturing & 25 & $50 \%$ & 27 & $54 \%$ \\
\hline $\begin{array}{l}\text { Transportation, communication, electric, } \\
\text { gas and sanitary services }\end{array}$ & 8 & $16 \%$ & 12 & $24 \%$ \\
\hline Wholesale trade & 2 & $4 \%$ & 3 & $6 \%$ \\
\hline Retail trade & 1 & $2 \%$ & 2 & $4 \%$ \\
\hline Finance, insurance and real estate & 2 & $4 \%$ & 0 & $0 \%$ \\
\hline Service & 12 & $24 \%$ & 6 & $12 \%$ \\
\hline Total & 50 & $100 \%$ & 50 & $100 \%$ \\
\hline
\end{tabular}

Tabel 1 menunjukan komposisi industri atas perusahaan yang dijadikan sampel. Berdasarkan total aset, perusahaan sampel di Indonesia dan Jepang lebih didominasi berdasarkan industri manufaktur. Tidak ada perusahaan jasa keuangan dan asuransi yang masuk dalam sampel di kedua negara tersebut.

Tabel 2.

Statistik Deskriptif

\begin{tabular}{lllrrc}
\hline Variable & Mean & Median & Maximum & Minimum & Std. Dev. \\
\hline Index TBL & 0.520758 & 0.563131 & 0.823232 & 0.186869 & 0.194505 \\
Index ECO & 0.677424 & 0.742424 & 0.878788 & 0.363636 & 0.149765 \\
Index NON_FIN & 0.442424 & 0.481061 & 0.795455 & 0.090909 & 0.226132 \\
Index SOC & 0.379242 & 0.363636 & 0.803030 & 0.090909 & 0.162196 \\
Indeks EVIRON & 0.505606 & 0.515152 & 0.984848 & 0.015152 & 0.314120 \\
SIZE & 6.819326 & 7.176360 & 8.512500 & 5.265596 & 0.931587 \\
LIQUID & 1.553703 & 1.345390 & 7.273020 & 0.122229 & 1.119080 \\
LEV & 0.245187 & 0.241715 & 0.628246 & 0.000161 & 0.148998 \\
PROFIT & 4.902900 & 2.125 .000 & 40.67000 & -16.87000 & 8.519325 \\
FOREIGN & 0.280000 & 0.000000 & 1.000 .000 & 0.000000 & 0.451261 \\
BOD_C & 1.964112 & 0.181818 & 8.200 .000 & 0.000000 & 9.788465 \\
IND & 0.550000 & 1.000 .000 & 1.000 .000 & 0.000000 & 0.500000 \\
CNTRY & 0.500000 & 0.500000 & 1.000 .000 & 0.000000 & 0.502519 \\
\hline
\end{tabular}

Keterangan : TBL adalah Indek gabungan ekonomi, sosial dan lingkungan, NON_FIN adalah non-ekonomi, ECO: indeks Ekonomi, SOC: indeks sosial, EVIRON: Indeks Lingkungan

Tabel 2 menunjukan deskriptif statistik untuk dependen dan independen variabel.
Secara rata-rata, pengungkapan item ekonomi lebih tinggi dibandingkan 
pengungkapan sosial dan lingkungan. Pengungkapan sosial paling rendah dibanding ekonomi dan sosial. Rata-rata pengungkapan TBL yaitu sebesar 52\% atau setengah dari total indeks pengungkapan TBL (66 item kali 3 konten analisis) dilakukan oleh perusahaan sample di Indonesia dan Jepang. Namun hanya 37\% pengungkapan sosial dan $44 \%$ pengungkapan lingkungan yang dilakukan. Rata-rata dari current ratio sebesar 1.5 , leverage 1.5 , return on asset sebesar 4.9, kepemilikan perusahaan asing sebesar $28 \%$, dan $2 \%$ komposisi independen direktur terhadap total direktur yang ada diperusahaan.

\section{ANALISIS DAN PEMBAHASAN}

Pada tabel 2 dapat dilihat bahwa secara keseluruhan Jepang memiliki tingkat pengungkapan TBL (ekonomi, sosial dan lingkungan) yang lebih tinggi dibandingkan Indonesia, terutama pada pengungkapan lingkungan. Hal ini konsisten dengan penelitan Jennifer Ho dan Taylor (2007) yang mengatakan bahwa pengungkapan lingkungan pada perusahaan di negara Jepang adalah tinggi. Sedangkan pengungkapan ekonomi tidak terlalu jauh perbedaannya.

Tabel 3 menyajikan hasil regresi berganda yang terdiri dari 2 panel yaitu Panel A dengan sampel 100 yang terdiri dari perusahaan Jepang dan Indonesia sedangkan panel B merupakan hasil regresi pada perusahaan sampel Indonesia yang berjumlah 50 sampel perusahaan. Masing-masing panel terdiri dari 5 kolom pengujian yaitu kolom (1) pengungkapan TBL (total pengungkapan ekonomi, sosial dan lingkungan), kolom (2) pengungkapan ekonomi, kolom (3) pengungkapan sosial, kolom (4) pengungkapan lingkungan dan kolom (5) pengungkapan non-ekonomi.

Panel A merupakan hasil pengujian atas pengungkapan TBL menunjukkan bahwa koefisien SIZE positif signifikan pada $1 \%$ mengindikasikan bahwa luas pengungkapan TBL berdasarkan pada ukuran perusahaan, semakin besar perusahaan maka jumlah pengungkapan TBL akan semakin besar, sehingga hipotesa (1) diterima, dan hasil sesuai dengan penelitian-penelitian sebelumnya. Koefisien LIQUID positif signifikan pada $1 \%$, mengindikasikan bahwa perusahaan yang memiliki tingkat likuiditas yang semakin baik cenderung akan semakin mengungkapkan TBL, sehingga mendukung hipotesa (4), hasil kontras dengan penelitian yang dilakukan Jennifer Ho dan Taylor (2007) yang menemukan hubungan negatif antara tingkat likuiditas dengan pengungkapan. Koefisien COUNTRY negatif signifikan pada tingkat 10\%, mengindikasikan jumlah 
pengungkapan TBL lebih besar untuk perusahaan Jepang dibandingkan perusahaan Indonesia, dimana o untuk perusahaan Jepang dan 1 untuk perusahaan Indonesia, hal ini diduga karena negara Jepang telah memiliki peraturan mengenai pengungkapan TBL yang walaupun tidak bersifat mandatory namun banyak perusahaan di Jepang memberikan informasi berdasarkan pedoman tersebut secara sukarela.

Dari hasil pengujian yang terpisah antara ekonomi, sosial, lingkungan, dan non ekonomi ternyata menghasilkan temuan yang sama dengan yang dihasilkan pada pengujian pengungkapan TBL (kolom 1) yaitu signifikan untuk SIZE dan LIQUID, namun pada pengungkapan sosial faktor negara tidak mempengaruhi pengungkapan yang terjadi, sehingga hipotesa 8 ditolak khusus untuk pengujian pengungkapan sosial. Sedangkan hasil penelitian ini tidak mendukung hipotesa 2, 3, 5, 6, dan 7 karena tidak signifikan mempengaruhi pengungkapan.

Untuk melihat kondisi di Indonesia, maka dilakukan pengujian untuk sampel perusahaan di Indonesia, dengan hasil regresi yang terdapat pada Panel B. Hasil sama dengan panel A yaitu positif signifikan $1 \%$ pada SIZE dan LIQUID hanya berbeda pada kolom (4) yaitu pengungkapan lingkungan, sesuai prediksi bahwa INDUST positif signifikan pada $10 \%$, mengindikasikan bahwa ada perbedaan yang signifikan pengungkapan antara perusahaan manufaktur dan perusahaan non -manufaktur.

Tabel 3.

Hasil Analisa Regresi Berganda

\begin{tabular}{|c|c|c|c|c|c|c|}
\hline \multirow[b]{2}{*}{ Variabel } & \multirow[b]{2}{*}{$\begin{array}{l}\text { Predicted } \\
\text { Sign }\end{array}$} & \multicolumn{5}{|c|}{ Pengungkapan } \\
\hline & & $\begin{array}{c}\text { TBL } \\
(\text { Ekonomi }+ \text { sosial }+ \text { Lingku } \\
\text { ngan }) \\
(1)\end{array}$ & $\begin{array}{l}\text { Ekonomi } \\
\text { (2) }\end{array}$ & $\begin{array}{l}\text { Sosial } \\
\text { (3) }\end{array}$ & $\begin{array}{l}\underset{\mathrm{n}}{\text { Lingkunga }} \\
\qquad(4)\end{array}$ & $\begin{array}{l}\text { Non- } \\
\text { Ekonomi } \\
\text { (5) }\end{array}$ \\
\hline \multicolumn{7}{|c|}{ A. Sampel Indonesia dan Jepang (100) } \\
\hline & & $-0.3631(-1.587)$ & 0.0713 & $-0.2464(-$ & $-0.9143(-$ & $-0.5804(-$ \\
\hline \multirow[t]{2}{*}{ Intercept } & $?$ & & $(0.359)$ & $0.913)$ & $2.503)^{* *}$ & $2.059)^{* * *}$ \\
\hline & & $0.1306(4.294)^{* * *}$ & $\begin{array}{l}0.0905 \\
(3.435)^{* *}\end{array}$ & $\begin{array}{l}0.0932 \\
(2.601)^{* *}\end{array}$ & $\begin{array}{l}0.2081 \\
(4.286)^{* * * *}\end{array}$ & $\begin{array}{l}0.1507 \\
(4.021)^{* * *}\end{array}$ \\
\hline \multirow[t]{2}{*}{ SIZE } & + & & $*$ & & & \\
\hline & & $-0.0012(-0.821)$ & $-0.0007(-$ & $-0.0011(-$ & $-0.0019(-$ & $-0.0015(-$ \\
\hline \multirow[t]{2}{*}{ PROFIT } & $?$ & & $0.563)$ & $0.645)$ & $0.761)$ & $0.802)$ \\
\hline & + & $0.0408(3.823)^{* * *}$ & $\begin{array}{c}0.0174 \\
(1.886)^{*}\end{array}$ & $\begin{array}{l}0.0464 \\
(3.688)^{* *} \\
*\end{array}$ & $\begin{array}{l}0.0586 \\
(3.437)^{* * * *}\end{array}$ & $\begin{array}{l}0.0525 \\
(3.991)^{* * * *}\end{array}$ \\
\hline
\end{tabular}




\begin{tabular}{|c|c|c|c|c|c|c|}
\hline LEV & + & $-0.0916(-1.012)$ & $\begin{array}{l}-0.0098(- \\
0.125)\end{array}$ & $\begin{array}{l}-1576(- \\
1.477)\end{array}$ & $\begin{array}{l}-0.1073(- \\
0.743)\end{array}$ & $\begin{array}{l}-0.1324(- \\
1.188)\end{array}$ \\
\hline & & $0.0012(0.049)$ & 0.0079 & $-0.0245(-$ & 0.0201 & $-0.0021(-$ \\
\hline FOREIGN & + & & $(0.374)$ & $0.850)$ & $(0.516)$ & $0.071)$ \\
\hline & & $-0.0003(-0.324)$ & $-0.0003(-$ & 0.0002 & $-0.0009(-$ & $-0.0003(-$ \\
\hline BOD_C & + & & $0.355)$ & $(0.151)$ & $0.527)$ & $0.269)$ \\
\hline & & $0.0185(0.811)$ & 0.0159 & $-0.0119(-$ & 0.0514 & 0.0197 \\
\hline INDUST & $?$ & & $(0.808)$ & $0.442)$ & $(1.412)$ & $(0.703)$ \\
\hline & & $-0.1029(-1.835)^{*}$ & $-0.0852(-$ & $-0.0502(-$ & $-0.1734(-$ & $-0.1118(-$ \\
\hline COUNTRY & $?$ & & $1.753)^{*}$ & $0.760)$ & $1.936)^{*}$ & $1.818)^{*}$ \\
\hline Adjusted R2 & & 0.723305 & 0.649746 & 0.447287 & 0.729786 & 0.689435 \\
\hline
\end{tabular}

B. Sampel Indonesia (50)

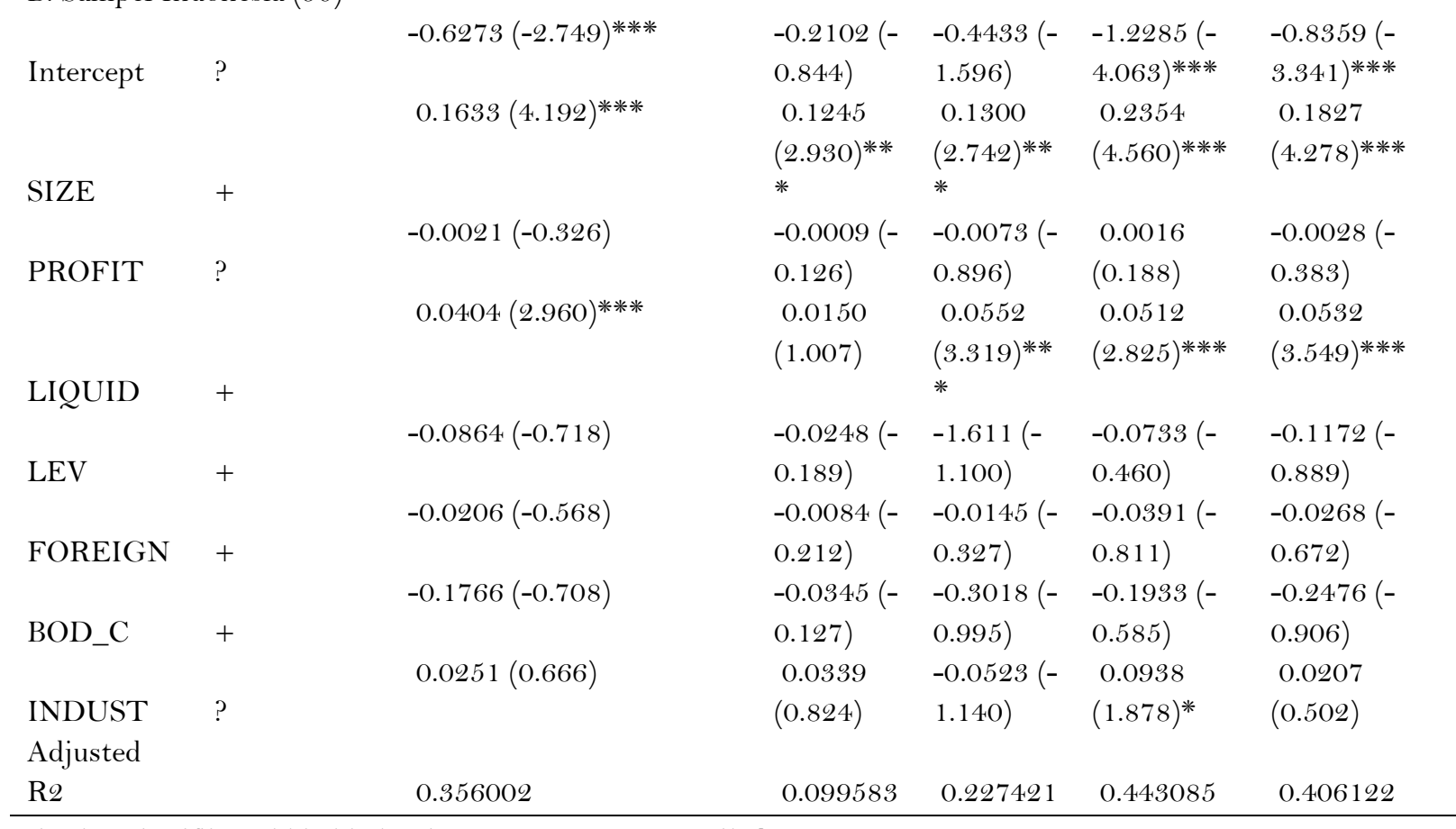

tingkat signifikan, $* * *, * *, *$ yaitu $1 \%, 5 \%, 10 \%$ two tailed

\section{KESIMPULAN DAN SARAN}

Tujuan dari penelitian ini adalah untuk menganalisa pengungkapan TBL dari 50 perusahaan terbesar di Indonesia dan di Jepang. Indonesia dan Jepang dijadikan sampel dalam penelitian ini karena jarang diteliti dalam berbagai penelitian Internasional terkait dengan pengungkapan lingkungan dan sosial, 2)
Jepang merupakan negara yang berdasarkan penelitian sebelumnya merupakan negara yang tinggi tingkat pengungkapan lingkungan sedangkan Indonesia rendah tingkat pengungkapan lingkungan sehingga untuk dengan mengkombinasikan keduanya diharapkan dapat melengkapi bukti yang ada. 3) Jepang dan Indonesia berbeda dalam budaya dan peraturan. 
66 item pengungkapan telah digunakan untuk area pengungkapan TBL yang dianalisa melalui 3 media yaitu laporan tahunan, website serta laporan terpisah lainnya seperti CSR report, Environmental Report, Sustainability Report, Environmental Sustainability Report, Environmental \& Social Reporting. Hasil penelitian menunjukan bahwa pengungkapan TBL (kombinsi ekonomi, sosial dan lingkungan) lebih tinggi pada perusahan dengan ukuran yang lebih besar, dan likuiditas yang lebih tinggi dan khusus untuk pengungkapan lingkungan faktor industri mempengaruhi luasnya pengungkapan lingkungan, yaitu lebih banyak untuk industri manufaktur.

Total pengungkapan TBL lebih di dominasi oleh pengungkapan nonekonomi. Dari hasil analisa diketahui bahwa pengungkapan lingkungan lebih paling tinggi untuk perusahaan Jepang, hal ini menunjukkan bahwa adanya perbedaan budaya dan regulasi antara Jepang dan Indonesia. Seperti Kementrian Lingkungan dan Kementrian Ekonomi, perdangangan dan Industri di Jepang memiliki pedoman untuk menyiapkan laporan lingkungan, walaupun laporan ini tidak bersifat wajib namun banyak perusahaan di Jepang yang secara sukarela mengeluarkan report tersebut, hal ini terbukti dari hasil penelitian ini. Sedangkan di Indonesia walaupun sudah ada kebijakan mengenai pengungkapan lingkungan dan sosial namun tidak ada pedoman khusus mengenai penyiapan laporan lingkungan yang dibuat oleh pemerintah, dan dari hasil penelitian ini terlihat bahwa perusahaan di Indonesia jarang yang melakukan pengungkapan lingkungan. Sehingga diharapkan pemerintah dapat memberikan pedoman khusus pengungkapan terutama terkait dengan isu sosial dan lingkungan sehingga mendorong perusahaan untuk meningkatkan aktivitas sosial dan lingkungan serta mengungkapkannya.

\section{Keterbatasan dan saran penelitian}

Penelitian ini hanya menggunakan 50 perusahaan untuk masing-masing negara, dan hanya menggunakan sampel perusahaan negara Indonesia dan Jepang, sehingga tidak dapat digeneralisasi, diharapkan penelitian selanjutnya dapat menggunakan sampel perusahaan yang lebih banyak dan sampel beberapa negara. Penelitian ini hanya menggunakan negara Indonesia dan Jepang sehingga faktor regulasi dan budaya yang ada tidak terlihat pengaruhnya, sehingga diharapkan apabila menambah sampel negara dapat melakukan pengujian mendalam mengenai budaya dan regulasi negara.

Sifat mengungkapkan yang sukarela menyebabkan kemungkinan 
adanya informasi tersembunyi yang tidak ada dalam media yang digunakan sehingga data menjadi kurang lengkap. Sehingga penelitian selanjutnya dapat memasukan informasi lainnya yang mungkin relevan.

Penelitian ini menggunakan indeks yang diperoleh dari hasil observasi pada laporan tahunan, laporan terpisah dan website sehingga ada kemungkinan terjadi subjektifitas, sehingga diharapkan penelitian selanjutnya dapat menggunakan beberapa reviewer untuk menghindari terjadinya subjektivita 


\section{DAFTAR PUSTAKA}

Chow, C.W., Wong-Boren, A. 1987. Voluntary Financial Disclosure by Mexican Corporations. The Accounting Review. Vol. 62, No. 3, pp. 533-541.

Debreceny R. G. Gray dan A. Rahman. 2002. The Determinants of Internet Financial Reporting. Journal of Accounting and Public Policy. Vol. 21, pp. 371-394.

Dowling, J., \& Pfeffer, J. 1975. Organizational legitimacy: Social values and organizational behavior. Pacific Sociological Review, Vol. 18, No. 1, pp. 122-138.

Jennifer Hoo. Li-Chin and Taylor. Martin E. 2007. An Empirical Analysis of Triple BottomLine Reporting and its Determinants: Evidence from The United States and Japan. Journal of International Financing Management and Accouting, Vol. 18, No. 2.

Gray, R., Kouhy, R., \& Lavers, S. 1995a., "Corporate Social And Environmental Reporting: A Review Of The Literature And A Longitudinal Study Of Uk Disclosure", Accounting Auditing \&' Accountability Journal, Vol. 8, No. 2, pp. 47- 77.

Gray, R., Owen, D. \& Adams, C. 1996, Accounting And Accountability: Changes And Challenges In Corporate Social And Environmental Reporting. Prentice Hall, London.

Guthrie, J., \& Parker, L. 1990. Corporate Social Disclosure Practice: A Comparative International Analysis. Advances In Public Interest Accounting, Vol. 3, pp. 159- 175.

Hackston, D., \& Milne, M. 1996. Some Determinants Of Social And Environmental Disclosures In New Zealand Companies. Accounting Auditing \&ْ Accountability Journal, Vol. 9, No. 1, pp. 77- 108.

Holland, L., Boon Foo, Y. 2003. Differences In Environmental Reporting Practices In The UK And The US: The Legal And Regulatory Context. The British Accounting Review. Vol. 35, pp. 1-18

Jensen, M.C., Meckling, W.H., 1976. Theory of The Firm: Managerial Behaviour, Agency Costs And Ownership Structure. Journal of Financial Economics October.

Lang, M., Lundholm, R., 1993. Cross-Sectional Determinants of Analyst Ratings of Corporate Disclosures. Journal of Accounting Research, Vol.31, No. 2, pp. 246-271.

Freedman, M., Jaggi B. 2005. Global warming, commitment to the Kyoto protocol, and accounting disclosures by the largest global public firms from polluting industries", The International Journal of Accounting, Vol. 40, pp. 215-232

Noe, C., 1999. Voluntary Disclosures and Insider Transactions. Journal of Accounting and Economics, Vol. 27, pp. 305-327. 
Nurhayati, Ratna, Alistair Brown, Greg Dan Tower. 2006. Natural Environment Disclosures Of Indonesian Listed Companies. Paper Submission AFAANZ Conference, July, 2006. Wellington, New Zealand. Working paper.

Patten, D. 1992. Intra-Industry Environmental Disclosures In Response To The Alaskan Oil Spill: A Note On Legitimacy Theory. Accounting, Organizations, And Society, pp. $471-475$.

Roberts, R. W. 1992. Determinants Of Corporate Social Responsibility Disclosure: An Application Of Stakeholder Theory. Accounting, Organization and Society, Vol. 17, pp. $595-6$ 